\title{
Factors associated with requesting and receiving euthanasia: a nationwide mortality follow-back study with a focus on patients with psychiatric disorders, dementia, or an accumulation of health problems related to old age
}

Kirsten Evenblij ${ }^{1 *}$ (D, H. Roeline W. Pasman ${ }^{1}$, Agnes van der Heide², Trynke Hoekstra ${ }^{3}$ and Bregje D. Onwuteaka-Philipsen ${ }^{1}$

\begin{abstract}
Background: Recently, euthanasia and assisted suicide (EAS) in patients with psychiatric disorders, dementia, or an accumulation of health problems has taken a prominent place in the public debate. However, limited is known about this practice. The purpose of this study was threefold: to estimate the frequency of requesting and receiving EAS among people with (also) a psychiatric disorder, dementia, or an accumulation of health problems; to explore reasons for physicians to grant or refuse a request; and to describe differences in characteristics, including the presence of psychiatric disorders, dementia, and accumulation of health problems, between patients who did and did not request EAS and between patients whose request was or was not granted.

Methods: A nationwide cross-sectional survey study was performed. A stratified sample of death certificates of patients who died between 1 August and 1 December 2015 was drawn from the central death registry of Statistics Netherlands. Questionnaires were sent to the certifying physician $(n=9351$, response $78 \%)$. Only deceased patients aged $\geq 17$ years and who died a non-sudden death were included in the analyses $(n=5361)$.

Results: The frequency of euthanasia requests among deceased people who died non-suddenly and with (also) a psychiatric disorder (11.4\%), dementia (2.1\%), or an accumulation of health problems (8.0\%) varied. Factors positively associated with requesting euthanasia were age (< 80 years), ethnicity (Dutch/Western), cause of death (cancer), attending physician (general practitioner), and involvement of a pain specialist or psychiatrist. Cause of death (neurological disorders, another cause) and attending physician (general practitioner) were also positively associated with receiving euthanasia. Psychiatric disorders, dementia, and/or an accumulation of health problems were negatively associated with both requesting and receiving euthanasia.

(Continued on next page)
\end{abstract}

\footnotetext{
* Correspondence: k.evenblij@vumc.nl

${ }^{1}$ Department of Public and Occupational Health, Amsterdam Public Health

Research Institute, Amsterdam UMC, Vrije Universiteit Amsterdam, P.O. Box

7057, 1007 MB Amsterdam, The Netherlands

Full list of author information is available at the end of the article
}

(c) The Author(s). 2019 Open Access This article is distributed under the terms of the Creative Commons Attribution 4.0 International License (http://creativecommons.org/licenses/by/4.0/), which permits unrestricted use, distribution, and reproduction in any medium, provided you give appropriate credit to the original author(s) and the source, provide a link to the Creative Commons license, and indicate if changes were made. The Creative Commons Public Domain Dedication waiver (http://creativecommons.org/publicdomain/zero/1.0/) applies to the data made available in this article, unless otherwise stated. 
(Continued from previous page)

Conclusions: EAS in deceased patients with psychiatric disorders, dementia, and/or an accumulation of health problems is relatively rare. Partly, this can be explained by the belief that the due care criteria cannot be met. Another explanation is that patients with these conditions are less likely to request EAS.

Keywords: Assisted suicide, Dementia, End-of-life care, Epidemiology, Euthanasia, Legislation, Medical decisionmaking, Policy, Psychiatry

\section{Background}

Patients suffering unbearably may wish to hasten their death. Since 2002, the Netherlands has been one of the few countries where euthanasia and assisted suicide (EAS) is allowed under strict conditions [1]. The practice of EAS is restricted to physicians who must adhere to the "statutory due care criteria," i.e., they must (1) be satisfied that the patient's request is voluntary and well-considered; (2) be satisfied that the patient's suffering is unbearable and without prospect of improvement; (3) have informed the patient about his situation and prognosis; (4) have come to the conclusion, together with the patient, that there is no reasonable alternative; (5) consult at least one other, independent physician; and (6) exercise EAS with due medical care and attention. Furthermore, the cause of suffering underlying the request must have a medical dimension, either somatic or psychiatric [1, 2], and physicians must report each case to the Regional Euthanasia Review Committees which review all EAS cases regarding whether the due care criteria were met.

In the past decade, the percentage of all deceased patients in the Netherlands who requested EAS prior to their death increased, from $5.2 \%$ in 2005 , to $6.7 \%$ in 2011 , and to $8.4 \%$ in 2015 [3]. Also, the percentage of requests that were carried out increased, from $37 \%$ in 2005 , to $45 \%$ in 2010 and to $55 \%$ in 2015 [4]. Hence, not only is there a growing demand for EAS, requests are also more likely to result in EAS. Some evidence, however, suggests that requesting and receiving euthanasia depends, at least to some extent, on the cause of suffering. For instance patients who have cancer are more likely to request EAS compared to those with cardiovascular diseases [5]. Patients with physical symptoms, cancer, and a short life expectancy are more likely to receive EAS than others, while patients with depressive symptoms are less likely [6-8]. Also, demographic and care factors have been reported to influence requesting and receiving EAS [5-8].

Recently, EAS in patients with psychiatric disorders, dementia, or an accumulation of health problems related to old age (from now, accumulation of health problems) has taken a prominent place in the public debate [9-13]. In the Dutch Euthanasia Code, this last category, an accumulation of health problems, is referred to as a range of, mostly degenerative, disorders such as visual impairment, hearing impairment, osteoporosis, arthrosis, balance disorders, and cognitive decline [14]. Though the numbers are small, reports of the Euthanasia Review Committees have shown that the absolute number of EAS cases in people whose primary cause of suffering was a psychiatric disorder, dementia, or an accumulation of health problems has increased over the past 5 years [15-17].

Using a nationwide sample of deceased people, we studied requests for EAS in people with and without these conditions focusing on the following questions: How many deaths among people with psychiatric disorders, dementia, and accumulation of health problems were preceded by a request for EAS and how many of these requests were granted? What are the reasons to grant or refuse a request for EAS? Which patient and care characteristics, including the presence of psychiatric disorders, dementia, and an accumulation of health problems, are associated with a patient requesting EAS and with a patient receiving EAS?

\section{Methods}

\section{Design and population}

In 2015, a nationwide mortality follow-back study was performed to estimate the frequency of requesting and receiving EAS among people with (also) a psychiatric disorder, dementia, or an accumulation of health problems; to explore reasons for physicians to grant or refuse a request; and to describe differences in characteristics, including the presence of psychiatric disorders, dementia, and accumulation of health problems, between patients who did and did not request EAS and between patients whose request was or was not granted. The study was largely similar to previous mortality follow-back studies done in 1990, 1995, 2001, 2005, and 2010 [3, 4, 18-21]. A stratified sample of death certificates of persons who died between 1 of August and 1 of December 2015 was obtained from the central death registry of Statistics Netherlands. Death certificates were stratified into 10 strata based on the likelihood of the patient having made an end-of-life decision. The certifying physicians of the sampled cases received a questionnaire focusing on end-of-life decisions that might have preceded the death of the patient involved. A reminder was 
sent to those who had not returned the questionnaire. Of the 9351 questionnaires sent, 7277 were returned (response $78 \%$ ). In this study, only those who died a non-sudden death and who were aged 17 years or older were included $(n=5361)$. Ethical approval was not required for the posthumous collection of anonymous patient data [22]. Further details of the study design are described elsewhere [3].

\section{Questionnaire}

A four-page written questionnaire was sent to the physicians who signed the death certificates. The questionnaire was largely similar to the previous mortality follow-back studies $[3,4,18-21]$. It contained questions about the medical decision-making that had preceded death, whether the patient had requested for euthanasia, the reasons for granting or refusing the request, and questions about the medical care during the last month before death such as the involvement of caregivers for palliative consultation and psychosocial and spiritual issues. To obtain insight into EAS requests from people with a psychiatric disorder, dementia, and/or an accumulation of health problems (related to old age), a new question was added to the questionnaire about whether the patient had a psychiatric disorder, dementia, and/or an accumulation of health problems (yes/no). No description of these groups was provided to the physicians to classify patients; thus, physicians will most likely have interpreted these categories in the context of the Dutch euthanasia act and the current debate. The cause of death and specialty of the certifying physician were derived from the death certificate.

\section{Analysis}

Statistical analyses were carried out using IBM SPSS version 22 (IBM Analytics). For presenting the frequencies of (requests for) EAS as well as the reasons for granting or refusing the requests, the results were made representative of all deaths during 2015 by weighting the data for stratification and response by patient's sex, age, ethnic origin, and place and cause of death. This weighting procedure was similar to previous mortality follow-back studies [3, 4, 18-21]. Due to this procedure, the percentages that are reported cannot be derived from the absolute unweighted numbers.

Two multivariable logistic regression models were developed: one to identify factors associated with patients requesting EAS and one to identify factors associated with receiving EAS. The latter model was developed on a subset of the sample: patients who made an EAS request. First, the univariable association between each independent variable and the dependent variables (requesting EAS and receiving EAS) was analyzed. Next, all variables associated with requesting and receiving
EAS ( $p$ value $<0.10)$ were entered in a multivariable model. Subsequently, a manual backward selection procedure was applied until only variables with $p<0.10$ remained. In both models, the eligible independent variables were age (17-64, 65-79, > 80 years); sex (female/ male); marital status (married/unmarried); ethnicity (Dutch and Western immigrants/non-Western immigrants); cause of death (cancer, cardiovascular disorder, pulmonary disorder, neurological disorder, or other); the presence of a psychiatric disorder (yes/no), dementia (yes/ no), or an accumulation of health problems (yes/no); specialty of the certifying physician (general practitioner, medical specialist, or elderly care physician); involvement (yes/no) of the following caregivers in the last month of life, namely palliative care consultant/team, specialist pain control, psychiatrist/psychologist, and pastor [5-8]. Results are presented as frequencies, ORs, and 95\% CIs.

\section{Extra analyses}

In the multivariable model identifying factors associated with requesting EAS, the ORs and 95\% CIs of cause of death changed drastically compared to the univariable model. Sensitivity analyses showed this was mainly driven by (i) collinearity between two variables, dementia and attending physicians; (ii) strong associations between cause of death, requesting EAS, and dementia and between cause of death, requesting EAS, and attending physician; and (iii) empty cells demonstrating the likelihood of unstable models. Therefore, we also performed the multivariable analyses for both requesting EAS and receiving EAS without dementia and attending physician. In these models, there was no indication for the issues described; the ORs and 95\% CI of the variables did not change substantially compared to the univariable analyses. The results of the multivariable regression analyses including all independent variables (including dementia and attending physician) are reported as main outcomes.

\section{Results \\ Description of the study sample}

Of the 5361 deceased patients aged $\geq 17$ years and whose death was non-sudden, $183(3.4 \%)$ had a psychiatric disorder, 803 (15.0\%) dementia, and 918 (17.1\%) an accumulation of health problems, possibly next to the illness that caused their death. In people with a psychiatric disorder, dementia, or an accumulation of health problems, the most frequently reported cause of death was "other." Of the people with dementia, 25.3\% died of a neurological disorder (including dementia), and of the people with an accumulation of health problems, $22.1 \%$ died of a cardiovascular disorder. Among all deceased patients who died non-suddenly, 37\% died due to cancer. The characteristics of the study sample are provided in Table 1. 
Table 1 Characteristics of the sample stratified for psychiatric disorder, dementia, and/or an accumulation of health problems

\begin{tabular}{|c|c|c|c|c|c|c|c|c|}
\hline & \multicolumn{2}{|c|}{$\begin{array}{l}\text { Psychiatric } \\
\text { disorder } \\
\text { Total } n=183\end{array}$} & \multicolumn{2}{|c|}{$\begin{array}{l}\text { Dementia } \\
\text { Total } n=803\end{array}$} & \multicolumn{2}{|c|}{$\begin{array}{l}\text { Accumulation of } \\
\text { health problems } \\
\text { Total } n=918\end{array}$} & \multicolumn{2}{|c|}{$\begin{array}{l}\text { All deceased patients who } \\
\text { died non-suddenly } \\
\text { Total } n=5361\end{array}$} \\
\hline & $\bar{N}$ & $\%^{1}$ & $\bar{N}$ & $\%^{1}$ & $N$ & $\%^{1}$ & $N$ & $\%^{1}$ \\
\hline \multicolumn{9}{|l|}{ Patient characteristics } \\
\hline \multicolumn{9}{|l|}{ Sex } \\
\hline Male & 91 & 39.1 & 305 & 35.4 & 321 & 32.3 & 2672 & 45.9 \\
\hline Female & 92 & 60.9 & 498 & 64.6 & 597 & 67.7 & 2689 & 54.1 \\
\hline \multicolumn{9}{|l|}{ Age } \\
\hline $17-64$ & 63 & 19.7 & 7 & 0.8 & 2 & 0.0 & 1028 & 12.6 \\
\hline $65-79$ & 48 & 22.4 & 158 & 17.4 & 101 & 8.8 & 1936 & 30.6 \\
\hline $80+$ & 72 & 57.8 & 638 & 81.8 & 815 & 91.1 & 2397 & 56.8 \\
\hline \multicolumn{9}{|l|}{ Marital status } \\
\hline Married & 45 & 21.2 & 257 & 29.8 & 221 & 21.9 & 2538 & 41.7 \\
\hline Unmarried & 138 & 78.8 & 546 & 70.2 & 697 & 78.1 & 2823 & 58.3 \\
\hline \multicolumn{9}{|l|}{ Ethnicity* } \\
\hline Non-Western immigrants & 27 & 3.7 & 74 & 1.5 & 87 & 1.9 & 605 & 2.9 \\
\hline Dutch, Western immigrants & 133 & 96.3 & 729 & 98.5 & 829 & 98.1 & 4722 & 97.1 \\
\hline \multicolumn{9}{|l|}{ Cause of death } \\
\hline Cancer & 50 & 15.4 & 108 & 6.1 & 179 & 9.6 & 3128 & 37.1 \\
\hline Cardiovascular disorder & 13 & 8.8 & 82 & 10.4 & 197 & 22.1 & 540 & 14.9 \\
\hline Pulmonary disorder & 14 & 11.9 & 43 & 7.0 & 104 & 13.7 & 285 & 8.5 \\
\hline Neurological disorder & 27 & 16.4 & 195 & 25.3 & 138 & 15.6 & 518 & 12.5 \\
\hline Other & 79 & 47.5 & 375 & 51.2 & 300 & 38.9 & 890 & 27.0 \\
\hline \multicolumn{9}{|l|}{ Care characteristics } \\
\hline \multicolumn{9}{|l|}{ Attending physician } \\
\hline General practitioner & 92 & 30.7 & 221 & 24.0 & 514 & 52.5 & 3301 & 50.0 \\
\hline Medical specialist & 28 & 17.5 & 43 & 6.2 & 105 & 12.5 & 897 & 21.0 \\
\hline Elderly care physician & 63 & 51.8 & 539 & 69.8 & 299 & 35.0 & 1163 & 29.1 \\
\hline \multicolumn{9}{|c|}{ Involvement of palliative care consultant/team } \\
\hline No & 164 & 91.5 & 761 & 95.4 & 842 & 92.5 & 4360 & 85.1 \\
\hline Yes & 19 & 8.5 & 42 & 4.6 & 76 & 7.5 & 1001 & 14.9 \\
\hline \multicolumn{9}{|l|}{ Pain specialist } \\
\hline No & 178 & 98.5 & 801 & 99.7 & 905 & 98.9 & 5166 & 97.5 \\
\hline Yes & 5 & 1.5 & 2 & 0.3 & 13 & 1.1 & 195 & 2.5 \\
\hline \multicolumn{9}{|l|}{ Psychiatrist/psychologist } \\
\hline No & 116 & 65.3 & 689 & 86.3 & 859 & 94.3 & 5050 & 93.8 \\
\hline Yes & 67 & 34.7 & 114 & 13.7 & 59 & 5.7 & 311 & 6.2 \\
\hline \multicolumn{9}{|l|}{ Pastor } \\
\hline No & 156 & 82.3 & 676 & 84.4 & 782 & 84.6 & 4698 & 86.9 \\
\hline Yes & 27 & 17.7 & 127 & 15.2 & 136 & 15.4 & 663 & 13.1 \\
\hline
\end{tabular}

${ }^{1}$ Weighted column percentage. Deceased patients could have had a combination of psychiatric disorder, dementia, and/or an accumulation of health problems *Missing $n=34(0.6 \%)$

\section{Frequency of EAS requests}

Figure 1 shows that $11.2 \%$ of all patients who were aged $\geq 17$ years had requested EAS preceding their death. Of the people with a psychiatric disorder, $11.4 \%$ requested EAS. The prevalence of EAS requests was lower among people with an accumulation of health problems (8.0\%) 


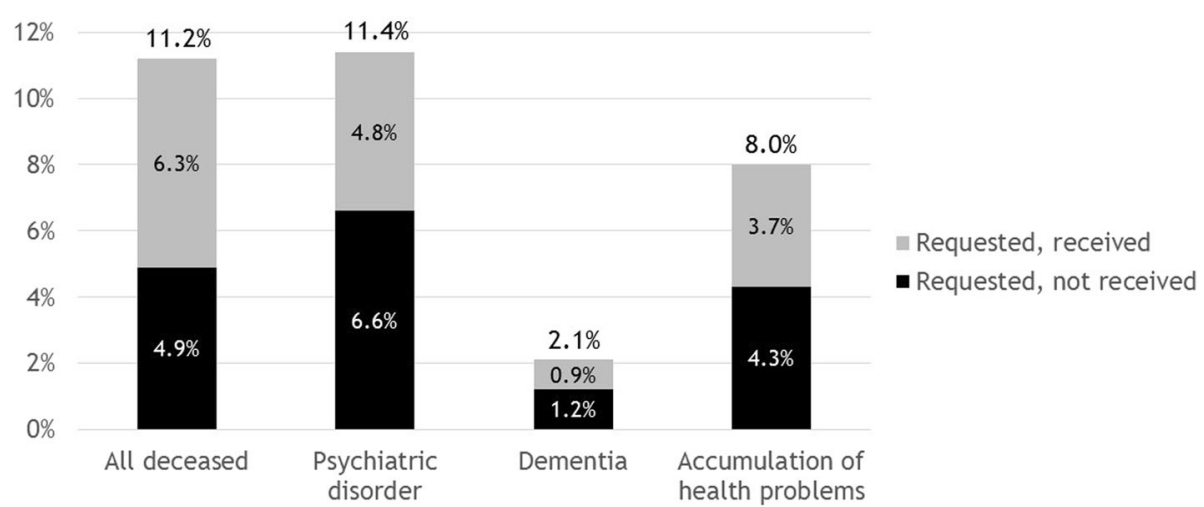

Fig. 1 Frequency of deceased patients who did or did not receive euthanasia. Percentage of requests carried out among all deceased patients who died non-suddenly, 56\% (6.3/11.2); people with psychiatric disorders, 42\% (4.8/11.4); people with dementia 43\% (0.9/2.1); and people with an accumulation of health problems, $46 \%$ (3.7/8.0)

and people with dementia requests $(2.1 \%)$. Six percent of all deceased patients had received euthanasia; this percentage was lower among people who had a psychiatric disorder (4.8\%), an accumulation of health problems (3.7\%), and/or dementia (0.9\%).

\section{Factors associated with requesting EAS}

In univariable analyses, all variables showed associations $(p<0.10)$ with requesting EAS, except for the presence of a psychiatric disorder (Table 2). In the multivariable analysis, sex, marital status, and the involvement of a palliative care consultant were no longer associated $(p<0.10)$ with requesting EAS. Compared with people aged 80 years or older whose death was non-sudden, people aged between 17 and 64 years (OR 1.65 [1.33-2.04]) and between 65 and 79 (OR 1.38 [1.15-1.66]) were more likely to request EAS. Dutch and Western immigrants were 8.49 (95\% CI 5.37-13.42) times more likely to request EAS compared with non-Western immigrants. Compared with people who died of cancer, people who died of cardiovascular disorders were less likely to request EAS while people who died of pulmonary disorders, neurological disorders, or another cause were more likely. People with an accumulation of health problems (OR 0.69 [0.53-0.90]) or dementia (OR (0.18 [0.12-0.28]) had lower odds of requesting EAS compared with those without these conditions. People whose attending physician was a medical specialist or an elderly care specialist had lower odds of requesting EAS (OR 0.07 [0.05-0.11] and OR 0.17 [0.13-0.23]) compared with people whose attending physician was a general practitioner. People who were supported by pain specialists (OR 2.08 [1.47-2.93]) and psychiatrists (OR 4.50 [3.15-6.41]) in the last month of life were more likely to request EAS while those supported by pastors were less likely (OR 0.77 [0.59-1.00]).

The results of the extra analysis without the variables dementia and attending physician (see the "Methods" section) were largely similar to the original multivariable model. However, people who died of cancer were now more likely to request EAS compared to people who died of any other cause. An accumulation of health problems dropped from the model.

\section{Reasons to grant or refuse the request}

Table 3 shows that across the full sample, the two most important reasons for the attending physician to grant the request were the lack of prospect of improvement $(81.9-94.6 \%)$ and the autonomy of the patient (72.4-85.8\%). In case of a psychiatric disorder, the presence of (severe) symptoms other than pain (75.4\%) and expected suffering (53.5\%) were also important reasons. In case of dementia, the loss of dignity $(73.7 \%)$ and expected suffering of the patient (49.1\%) were important. Finally, in case of an accumulation of health problems, the presence of symptoms other than pain (48.7\%) and loss of dignity (54.8\%) were both important reasons to grant the request. Among those with a psychiatric disorder, dementia, or an accumulation of health problems, the most important reason to refuse the request was that the due care criteria were not met, especially regarding the well-considered nature of the request. Among all deceased patients, the most important reason was that the patient died before the request was granted.

\section{Factors associated with receiving EAS}

Table 4 shows associations between receiving EAS and patient and care characteristics. In univariable analyses, age, cause of death, the presence of a psychiatric disorder and an accumulation of health problems, attending physician, and the involvement of a palliative care consultant/team and pastor showed associations $(p<0.10)$ with receiving EAS. In multivariable analysis, most associations remained significant. People who died of neurological disorders or 
Table 2 Factors associated to requesting EAS (people above the age of 16 whose death was non-sudden)

\begin{tabular}{|c|c|c|c|c|c|c|c|c|c|}
\hline \multirow{3}{*}{ Patient characteristics } & \multirow{2}{*}{$\begin{array}{l}\text { Absolute number } \\
\text { in sample } \\
N=5361\end{array}$} & \multirow{2}{*}{$\begin{array}{l}\text { No EAS } \\
\text { request } \\
N=4243 \\
\text { Row } \%^{\dagger}\end{array}$} & \multirow{2}{*}{$\begin{array}{l}\text { EAS } \\
\text { request } \\
N=1118 \\
\text { Row } \%^{\dagger}\end{array}$} & \multirow{2}{*}{$\begin{array}{l}\text { Univariable I } \\
\text { ogistic regression } \\
\text { Odds ratio } \\
(95 \% \mathrm{Cl})\end{array}$} & \multirow{2}{*}{$p$} & \multicolumn{2}{|l|}{$\begin{array}{l}\text { Multivariable } \\
\text { logistic regression }\end{array}$} & \multirow{2}{*}{$\begin{array}{l}\text { Sensitivity } \\
\text { analysis } \\
\text { Odds ratio } \\
(95 \% \mathrm{Cl})\end{array}$} & \multirow[b]{2}{*}{$p$} \\
\hline & & & & & & $\begin{array}{l}\text { Odds ratio } \\
(95 \% \mathrm{Cl})\end{array}$ & $p$ & & \\
\hline & & & & & & & & & \\
\hline \multicolumn{10}{|l|}{ Sex } \\
\hline Male & 2672 & 87.1 & 12.9 & Reference & & & & & \\
\hline Female & 2689 & 90.3 & 9.7 & $0.84(0.74-0.96)$ & 0.011 & - & & - & \\
\hline \multicolumn{10}{|l|}{ Age } \\
\hline $17-64$ & 1028 & 80.2 & 19.8 & 2.29 (1.92-2.73) & $<0.001$ & $1.65(1.33-2.04)$ & $<0.001$ & $2.13(1.75-2.59)$ & $<0.001$ \\
\hline $65-79$ & 1936 & 86.0 & 14.0 & $1.82(1.56-2.12)$ & $<0.001$ & $1.38(1.15-1.66)$ & 0.001 & 1.59 (1.35-1.88) & $<0.001$ \\
\hline $80+$ & 2397 & 92.2 & 7.8 & Reference & & Reference & & Reference & \\
\hline \multicolumn{10}{|l|}{ Marital status } \\
\hline Married & 2538 & 85.9 & 14.1 & Reference & & & & & \\
\hline Unmarried & 2823 & 90.9 & 9.1 & $0.71(0.63-0.81)$ & $<0.001$ & - & & - & \\
\hline \multicolumn{10}{|l|}{ Ethnicity ${ }^{\ddagger}$} \\
\hline $\begin{array}{l}\text { Non-Western } \\
\text { immigrants }\end{array}$ & 605 & 96.9 & 3.1 & Reference & & Reference & & & \\
\hline $\begin{array}{l}\text { Dutch, Western } \\
\text { immigrants }\end{array}$ & 4722 & 88.6 & 11.4 & $8.36(5.38-12.98)$ & $<0.001$ & $8.49(5.37-13.42)$ & $<0.001$ & $9.24(5.91-14.44)$ & $<0.001$ \\
\hline \multicolumn{10}{|l|}{ Cause of death } \\
\hline Cancer & 3128 & 81.1 & 18.9 & Reference & & Reference & & Reference & \\
\hline $\begin{array}{l}\text { Cardiovascular } \\
\text { disorders }\end{array}$ & 540 & 94.2 & 5.8 & $0.29(0.22-0.40)$ & $<0.001$ & $0.64(0.46-0.89)$ & 0.009 & $0.40(0.30-0.55)$ & $<0.001$ \\
\hline Pulmonary disorders & 285 & 87.7 & 12.3 & $0.77(0.57-1.03)$ & 0.077 & $1.94(1.37-2.76)$ & $<0.001$ & $0.95(0.70-1.29)$ & 0.772 \\
\hline $\begin{array}{l}\text { Neurological } \\
\text { disorders }\end{array}$ & 518 & 94.3 & 5.7 & $0.57(0.45-0.73)$ & $<0.001$ & $1.85(1.37-2.51)$ & $<0.001$ & $0.69(0.53-0.89)$ & 0.004 \\
\hline Other & 890 & 94.2 & 5.8 & $0.42(0.34-0.52)$ & $<0.001$ & $1.42(1.08-1.88)$ & 0.012 & $0.55(0.43-0.69)$ & $<0.001$ \\
\hline \multicolumn{10}{|l|}{ A psychiatric disorder } \\
\hline No & 5178 & 88.8 & 11.2 & Reference & & $\mathrm{NE}$ & & NE & \\
\hline Yes & 183 & 88.6 & 11.4 & $0.99(0.69-1.43)$ & 0.976 & & & & \\
\hline \multicolumn{10}{|c|}{ An accumulation of health problems } \\
\hline No & 4443 & 87.7 & 12.3 & Reference & & Reference & & & \\
\hline Yes & 918 & 92.0 & 8.0 & $0.50(0.40-0.61)$ & $<0.001$ & $0.69(0.53-0.90)$ & 0.005 & - & \\
\hline \multicolumn{10}{|l|}{ Dementia } \\
\hline No & 4558 & 86.0 & 14.0 & Reference & & Reference & & & \\
\hline Yes & 803 & 97.9 & 2.1 & $0.13(0.09-0.19)$ & $<0.001$ & $0.18(0.12-0.28)$ & $<0.001$ & $\mathrm{NE}$ & \\
\hline \multicolumn{10}{|l|}{ Care characteristics } \\
\hline \multicolumn{10}{|l|}{ Attending physician ${ }^{\S}$} \\
\hline General practitioner & 3301 & 81.2 & 18.8 & Reference & & Reference & & & \\
\hline Medical specialist & 897 & 96.7 & 3.3 & $0.09(0.07-0.13)$ & $<0.001$ & $0.07(0.05-0.11)$ & $<0.001$ & NE & \\
\hline $\begin{array}{l}\text { Elderly care } \\
\text { physician }\end{array}$ & 1163 & 96.1 & 3.9 & $0.14(0.10-0.18)$ & $<0.001$ & $0.17(0.13-0.23)$ & $<0.001$ & $\mathrm{NE}$ & \\
\hline \multicolumn{10}{|c|}{ Care givers involved in the last month of life } \\
\hline \multicolumn{10}{|c|}{ Palliative care consultant/team } \\
\hline Not involved & 4360 & 90.1 & 9.9 & Reference & & & & & \\
\hline Involved & 1001 & 81.6 & 18.4 & $1.43(1.22-1.68)$ & $<0.001$ & - & - & - & \\
\hline
\end{tabular}


Table 2 Factors associated to requesting EAS (people above the age of 16 whose death was non-sudden) (Continued)

\begin{tabular}{|c|c|c|c|c|c|c|c|c|c|}
\hline & $\begin{array}{l}\text { Absolute number } \\
\text { in sample }\end{array}$ & $\begin{array}{l}\text { No EAS } \\
\text { request }\end{array}$ & $\begin{array}{l}\text { EAS } \\
\text { request }\end{array}$ & $\begin{array}{l}\text { Univariable I } \\
\text { ogistic regression }\end{array}$ & & $\begin{array}{l}\text { Multivariable } \\
\text { logistic regression }\end{array}$ & & $\begin{array}{l}\text { Sensitivity } \\
\text { analysis }\end{array}$ & \\
\hline & $N=5361$ & $\begin{array}{l}N=4243 \\
\text { Row } \%^{\dagger}\end{array}$ & $\begin{array}{l}N=1118 \\
\text { Row } \%^{\dagger}\end{array}$ & $\begin{array}{l}\text { Odds ratio } \\
(95 \% \mathrm{Cl})\end{array}$ & $p$ & $\begin{array}{l}\text { Odds ratio } \\
(95 \% \mathrm{Cl})\end{array}$ & $p$ & $\begin{array}{l}\text { Odds ratio } \\
(95 \% \mathrm{Cl})\end{array}$ & $p$ \\
\hline \multicolumn{10}{|c|}{ Specialist pain control } \\
\hline Not involved & 5166 & 89.3 & 10.7 & Reference & & Reference & & Reference & \\
\hline Involved & 195 & 69.7 & 30.2 & $2.31(1.71-3.11)$ & $<0.001$ & $2.08(1.47-2.93)$ & $<0.001$ & $1.82(1.32-2.50)$ & $<0.001$ \\
\hline \multicolumn{10}{|c|}{ Psychiatrist/psychologist } \\
\hline Not involved & 5050 & 89.1 & 10.9 & Reference & & Reference & & Reference & \\
\hline Involved & 311 & 84.6 & 15.4 & $1.44(1.11-1.86)$ & 0.006 & $4.50(3.15-6.41)$ & $<0.001$ & $2.05(1.54-2.73)$ & $<0.001$ \\
\hline \multicolumn{10}{|l|}{ Pastor } \\
\hline Not involved & 4698 & 88.5 & 11.5 & Reference & & Reference & & Reference & \\
\hline Involved & 663 & 90.9 & 9.1 & $0.55(0.44-0.70)$ & $<0.001$ & $0.77(0.59-1.00)$ & 0.050 & $0.53(0.42-0.68)$ & $<0.001$ \\
\hline
\end{tabular}

another cause had 4.70 [95\% CI 2.09-10.58] and 2.38 [95\% CI 1.34-4.26] times higher odds of receiving EAS compared with people who died of cancer. People with a psychiatric disorder and an accumulation of health problems had lower odds of receiving EAS compared with people without these conditions (OR 0.38 [0.18-0.82] and OR 0.62 [0.36-1.05]). People whose attending physician was a medical specialist or an elderly care specialist were less likely to receive EAS (OR 0.13 [0.06-0.27] and OR 0.16 [0.09-0.28]) compared with people whose attending physician was a general practitioner. Those who were supported by a palliative care consultant in the last month of life were also less likely to receive EAS (OR 0.70 [0.50-0.98]).

The results of the extra analysis without the variables dementia and attending physician (see the "Methods" section) were largely similar to the original multivariable model except for the negative association found between pastor and receiving EAS.

\section{Discussion}

The frequency of EAS requests among deceased people who died non-suddenly and who had psychiatric disorders (11.4\%), dementia (2.1\%), and/or an accumulation of health problems (8.0\%) varied. Less than half of these requests led to EAS. Factors positively associated with requesting EAS were age ( $<80$ years), ethnicity (Dutch/ Western), cause of death (cancer), attending physician (general practitioner), and involvement of pain specialist and psychiatrist. Cause of death (neurological disorders or another cause) and attending physician (general practitioner) were also positively associated with receiving euthanasia. Psychiatric disorders, dementia, and accumulation of health problems were negatively associated with requesting and receiving EAS.
EAS in people with psychiatric disorders, dementia, and an accumulation of health problems

EAS in people with psychiatric disorders, dementia, and an accumulation of health problems is a highly debated subject, but this practice rarely occurs. Partially, this can be explained by reluctance of physicians to perform EAS in these patients [23]. Our results showed that the proportion of euthanasia requests that was carried out was lower among people with psychiatric conditions (42\%), dementia (43\%), and an accumulation of health problems (46\%) compared to all non-sudden deceased people (56\%). Moreover, having a psychiatric disorder or an accumulation of health problems was statistically significantly associated with a lower likelihood of having a request being carried out. Previous research has also shown that physicians consider it less likely to perform EAS in patients with a psychiatric disorder, dementia, and/or an accumulation of health problems compared to patients with a severe and life-limiting somatic illness such as cancer [23-25]. Our results suggest that the presence of a psychiatric disorder, dementia, and/or an accumulation of health problems may complicate the decision to grant a request, even if the patient also suffers from a severe and life-limiting somatic illness, such as cancer. The main reasons to refuse a request are doubts about whether the request was well-considered and about the unbearableness of the suffering. These findings corroborate previous studies [26, 27].

This study is the first to show that people with dementia or an accumulation of health problems are less likely to request EAS compared to people without these conditions which may explain part of the lower frequency of EAS in people with these conditions. 
Table 3 Reasons for either or not granting the EAS request stratified for psychiatric disorder, dementia, and/or an accumulation of health problems

\begin{tabular}{|c|c|c|c|c|}
\hline & $\begin{array}{l}\text { Deceased with a } \\
\text { psychiatric disorder } \\
(n=183) \%^{1}\end{array}$ & $\begin{array}{l}\text { Deceased with } \\
\text { dementia }(n=803) \%^{1}\end{array}$ & $\begin{array}{l}\text { Deceased with an accumulation } \\
\text { of health problems }(n=918) \%{ }^{1}\end{array}$ & $\begin{array}{l}\text { All deceased patients who } \\
\text { died non-suddenly }(n=5361) \%{ }^{1}\end{array}$ \\
\hline $\begin{array}{l}\text { Reasons for the physician to grant } \\
\text { the request and perform } \\
\text { euthanasia* }\end{array}$ & $N=24$ & $N=22$ & $N=80$ & $N=845$ \\
\hline No prospect of improvement & 87.3 & 94.6 & 83.4 & 81.9 \\
\hline Autonomy of the patient & 85.8 & 72.4 & 81.0 & 80.7 \\
\hline $\begin{array}{l}\text { (Severe) symptoms other than } \\
\text { pain }\end{array}$ & 75.4 & 26.2 & 48.7 & 61.2 \\
\hline Loss of dignity & 32.0 & 73.7 & 54.8 & 59.1 \\
\hline (Severe) pain & 20.3 & 12.6 & 34.9 & 40.4 \\
\hline Expected suffering of the patient & 53.5 & 49.1 & 30.9 & 44.3 \\
\hline $\begin{array}{l}\text { Further treatment would be too } \\
\text { burdensome }\end{array}$ & 21.6 & 21.4 & 22.2 & 14.5 \\
\hline Other & 11.0 & 15.5 & 4.1 & 1.8 \\
\hline $\begin{array}{l}\text { Reasons for the request not } \\
\text { resulting in euthanasia* }\end{array}$ & $N=14$ & $N=9$ & $N=36$ & $N=273$ \\
\hline $\begin{array}{l}\text { Patient died before the request } \\
\text { could be granted }\end{array}$ & 13.0 & 8.1 & 23.5 & 53.1 \\
\hline $\begin{array}{l}\text { The criteria for due care were } \\
\text { not } \text { met* }^{*}\end{array}$ & 44.4 & 76.1 & 70.6 & 32.1 \\
\hline No well-considered request & 34.8 & 59.8 & 32.4 & 16.2 \\
\hline No unbearable suffering & 18.1 & 16.3 & 40.5 & 12.0 \\
\hline No hopeless suffering & 16.8 & 16.3 & 13.5 & 5.1 \\
\hline No voluntary request & 0 & 4.3 & 0 & 0.7 \\
\hline Generally & 8.3 & 10.1 & 5.6 & 4.3 \\
\hline Patient withdrew the request & 18.7 & 13.9 & 15.7 & 17.4 \\
\hline $\begin{array}{l}\text { Physician never willing } \\
\text { to perform euthanasia }\end{array}$ & 0 & 0 & 5.5 & 2.1 \\
\hline Other & 29.0 & 21.5 & 14.7 & 9.4 \\
\hline
\end{tabular}

'Weighted column percentage

*More than one answer possible

Possibly, the lower frequency of requests among people with dementia and an accumulation of health problems can be explained by the slow and gradual decline characterizing both dementia and an accumulation of health problems leading to the gradual acceptance of a declining health condition [28-30]. In addition, in case of advanced dementia, patients lose the ability to make a well-considered request for EAS.

Due to the aging society, associated with an increasing number of older people suffering from multimorbidity, it is likely that the number of EAS requests from patients suffering from dementia and/or an accumulation of health problems related to old age will continue to grow $[31,32]$. The question of how policy makers and care providers should respond to these requests is, therefore, highly relevant.

\section{Characteristics associated with requesting and receiving EAS \\ Patient characteristics}

This study showed that younger people are more likely to request EAS which is consistent with previous studies in the Netherlands and Belgium [5, 6, 33]. Younger people tend to have more permissive and liberal attitudes compared to older people and are more likely to support EAS [34, 35]. Also, a strong positive association between ethnicity and requesting EAS was found, with Dutch or Western migrants being 8.5 times more likely to request EAS compared to non-Western migrants. Cultural and religious values and beliefs have frequently been reported to profoundly influence the perceptions of death and end-of-life decision-making [36-40]. 
Table 4 Factors associated with receiving EAS (people above the age of 16 whose death was non-sudden)

\begin{tabular}{|c|c|c|c|c|c|c|c|c|c|}
\hline \multirow{3}{*}{ Patient characteristics } & \multirow{2}{*}{$\begin{array}{l}\text { Absolute number } \\
\text { in the sample } \\
N=1118\end{array}$} & \multirow{2}{*}{$\begin{array}{l}\text { Request did not } \\
\text { result in EAS } \\
N=273 \%{ }^{1}\end{array}$} & \multirow{2}{*}{$\begin{array}{l}\text { Request did } \\
\text { result in EAS } \\
N=845 \%^{1}\end{array}$} & \multicolumn{2}{|l|}{$\begin{array}{l}\text { Univariable } \\
\text { logistic regression }\end{array}$} & \multicolumn{2}{|l|}{$\begin{array}{l}\text { Multivariable } \\
\text { logistic regression }\end{array}$} & \multicolumn{2}{|l|}{$\begin{array}{l}\text { Sensitivity } \\
\text { analysis }\end{array}$} \\
\hline & & & & $\begin{array}{l}\text { Odds ratio } \\
(95 \% \mathrm{Cl})\end{array}$ & $p$ & $\begin{array}{l}\text { Odds ratio } \\
(95 \% \mathrm{Cl})\end{array}$ & $p$ & $\begin{array}{l}\text { Odds ratio } \\
(95 \% \mathrm{Cl})\end{array}$ & $p$ \\
\hline & & & & & & & & & \\
\hline \multicolumn{10}{|l|}{ Sex } \\
\hline Male & 595 & 42.9 & 57.1 & Reference & & & & & \\
\hline Female & 523 & 44.7 & 55.3 & $1.14(0.87-1.50)$ & 0.349 & $\mathrm{NE}$ & & $\mathrm{NE}$ & \\
\hline \multicolumn{10}{|l|}{ Age } \\
\hline $17-64$ & 294 & 42.1 & 57.9 & $1.07(0.76-1.53)$ & 0.690 & - & & - & \\
\hline $65-79$ & 467 & 38.3 & 61.7 & $1.32(0.96-1.81)$ & 0.093 & - & & - & \\
\hline $80+$ & 357 & 50.0 & 50.0 & Reference & & & & & \\
\hline \multicolumn{10}{|l|}{ Marital status } \\
\hline Married & 604 & 44.7 & 55.3 & Reference & & & & & \\
\hline Unmarried & 514 & 42.8 & 57.2 & $1.21(0.92-1.59)$ & 0.184 & $N E$ & & $\mathrm{NE}$ & \\
\hline \multicolumn{10}{|l|}{ Ethnicity } \\
\hline $\begin{array}{l}\text { Non-Western } \\
\text { immigrants }\end{array}$ & 21 & 25.0 & 75.0 & Reference & & & & & \\
\hline $\begin{array}{l}\text { Dutch, Western } \\
\text { immigrants }\end{array}$ & 1091 & 43.8 & 56.2 & $1.27(0.49-3.31)$ & 0.622 & $\mathrm{NE}$ & & $\mathrm{NE}$ & \\
\hline \multicolumn{10}{|l|}{ Cause of death } \\
\hline Cancer & 808 & 40.7 & 59.3 & Reference & & Reference & & Reference & \\
\hline $\begin{array}{l}\text { Cardiovascular } \\
\text { disorders }\end{array}$ & 50 & 65.3 & 34.7 & $0.56(0.31-1.01)$ & 0.054 & $0.72(0.37-1.41)$ & 0.332 & $0.70(0.37-1.35)$ & 0.291 \\
\hline $\begin{array}{l}\text { Pulmonary } \\
\text { disorders }\end{array}$ & 60 & 57.6 & 42.4 & $0.87(0.48-1.55)$ & 0.628 & $1.53(0.77-3.03)$ & 0.221 & $1.02(0.55-1.90)$ & 0.942 \\
\hline $\begin{array}{l}\text { Neurological } \\
\text { disorders }\end{array}$ & 86 & 22.5 & 77.5 & $3.34(1.58-7.03)$ & 0.002 & $4.70(2.09-10.58)$ & $<0.001$ & $3.92(1.81-8.47)$ & 0.001 \\
\hline Other & 114 & 45.5 & 54.5 & $1.35(0.83-2.20)$ & 0.220 & $2.38(1.34-4.26)$ & 0.003 & $1.83(1.06-3.14)$ & 0.029 \\
\hline \multicolumn{10}{|c|}{ A psychiatric disorder } \\
\hline No & 1080 & 43.3 & 56.7 & Reference & & Reference & & Reference & \\
\hline Yes & 38 & 56.5 & 43.5 & $0.54(0.28-1.06)$ & 0.074 & $0.38(0.18-0.82)$ & 0.013 & $0.38(0.18-0.79)$ & 0.010 \\
\hline \multicolumn{10}{|c|}{ An accumulation of health problems } \\
\hline No & 1002 & 41.7 & 58.3 & Reference & & Reference & & Reference & \\
\hline Yes & 116 & 54.1 & 45.9 & $0.69(0.45-1.05)$ & 0.081 & $0.62(0.36-1.05)$ & 0.073 & $0.63(0.38-1.04)$ & 0.070 \\
\hline \multicolumn{10}{|l|}{ Dementia } \\
\hline No & 1087 & 43.1 & 56.9 & Reference & & & & & \\
\hline Yes & 31 & 59.3 & 40.7 & $0.78(0.36-1.72)$ & 0.545 & $\mathrm{NE}$ & & NE & \\
\hline \multicolumn{10}{|l|}{ Care characteristics } \\
\hline \multicolumn{10}{|l|}{ Attending physician } \\
\hline $\begin{array}{l}\text { General } \\
\text { practitioner }\end{array}$ & 1016 & 37.8 & 62.2 & Reference & & Reference & & & \\
\hline $\begin{array}{l}\text { Medical } \\
\text { specialist }\end{array}$ & 36 & 66.7 & 33.3 & $0.13(0.06-0.27)$ & $<0.001$ & $0.13(0.06-0.27)$ & $<0.001$ & $\mathrm{NE}$ & \\
\hline $\begin{array}{l}\text { Elderly care } \\
\text { physician }\end{array}$ & 66 & 79.4 & 20.6 & $0.19(0.12-0.32)$ & $<0.001$ & $0.16(0.09-0.28)$ & $<0.001$ & $\mathrm{NE}$ & \\
\hline
\end{tabular}


Table 4 Factors associated with receiving EAS (people above the age of 16 whose death was non-sudden) (Continued)

\begin{tabular}{|c|c|c|c|c|c|c|c|c|c|}
\hline & $\begin{array}{l}\text { Absolute number } \\
\text { in the sample }\end{array}$ & $\begin{array}{l}\text { Request did not } \\
\text { result in EAS }\end{array}$ & $\begin{array}{l}\text { Request did } \\
\text { result in EAS }\end{array}$ & $\begin{array}{l}\text { Univariable } \\
\text { logistic regression }\end{array}$ & & $\begin{array}{l}\text { Multivariable } \\
\text { logistic regression }\end{array}$ & & $\begin{array}{l}\text { Sensitivity } \\
\text { analysis }\end{array}$ & \\
\hline & $N=1118$ & $N=273 \%{ }^{1}$ & $N=845 \%^{1}$ & $\begin{array}{l}\text { Odds ratio } \\
(95 \% \mathrm{Cl})\end{array}$ & $p$ & $\begin{array}{l}\text { Odds ratio } \\
(95 \% \mathrm{Cl})\end{array}$ & $p$ & $\begin{array}{l}\text { Odds ratio } \\
(95 \% \text { Cl) }\end{array}$ & $p$ \\
\hline \multicolumn{10}{|c|}{ Care givers involved in the last month of life } \\
\hline \multicolumn{10}{|c|}{ Palliative care consultant/team } \\
\hline Not involved & 872 & 42.3 & 57.7 & Reference & & Reference & & Reference & \\
\hline Involved & 246 & 48.4 & 51.6 & $0.65(0.48-0.89)$ & 0.007 & $0.70(0.50-0.98)$ & 0.037 & $0.65(0.48-0.90)$ & 0.008 \\
\hline \multicolumn{10}{|c|}{ Specialist pain control } \\
\hline Not involved & 1046 & 43.4 & 56.6 & Reference & & & & & \\
\hline Involved & 72 & 48.8 & 51.2 & $0.90(0.52-1.54)$ & 0.688 & $\mathrm{NE}$ & & $\mathrm{NE}$ & \\
\hline \multicolumn{10}{|c|}{ Psychiatrist/psychologist } \\
\hline Not involved & 1034 & 42.8 & 57.2 & Reference & & & & & \\
\hline Involved & 84 & 54.7 & 45.3 & $0.75(0.46-1.21)$ & 0.237 & $\mathrm{NE}$ & & $\mathrm{NE}$ & \\
\hline \multicolumn{10}{|l|}{ Pastor } \\
\hline Not involved & 1029 & 42.1 & 57.9 & Reference & & & & & \\
\hline Involved & 89 & 58.2 & 41.8 & $0.49(0.31-0.77)$ & 0.002 & - & & $0.49(0.30-0.78)$ & 0.003 \\
\hline
\end{tabular}

- indicates the item was entered in the regression but was not significant ( $>0.10)$ and consequently eliminated in the stepwise procedure; NE indicates the item was not entered in the regression

tWeighted row percentage

‡6 missing (0.5\%)

People who died due to a neurological disorder were almost four times more likely to receive EAS compared to people with cancer which corresponds with previous findings [5, 33, 41]. ALS disease, which is known for its progressive, severe physical symptoms and lack of effective treatments, probably contributes the most to this finding.

\section{Care characteristics}

The involvement of a pain specialist and the involvement of a psychiatrist/psychologist in the last month of life were associated with higher likelihood of requesting EAS. This confirms previous research in Belgium and the Netherlands [5, 42]. Possibly, pain specialists and psychiatrists/psychologists stimulate patients to think and talk about their end-of-life wishes, including EAS, as autonomy and informed decision-making are key principles of palliative care [43]. Finally, prior to granting a request, a physician must be certain that there is no other reasonable solution; optimizing end-of-life care is one of them.

Multivariable regression analyses also showed that deceased patients who were attended by a general practitioner were more likely to request and receive EAS, supporting previous evidence [5]. The attendance of a general practitioner possibly provides more opportunity for discussing end-of-life wishes, including euthanasia, due to the long-term care relationship with the patient and the non-acute care setting.

\section{Strengths and limitations}

Major strengths of this study are the large nationwide sample which is the representative of all deaths in the Netherlands in 2015, the high response rate and few missing data. When interpreting the results, some limitations need to be considered. Physicians were asked whether the patient had either one or more of the following conditions: a psychiatric disorder, dementia, and an accumulation of health problems. Since this was a general, closed question, i.e., yes/no, it is unknown to what extent these conditions contributed to the suffering underlying the EAS request. Also, psychiatric disorders and an accumulation of health problems are very broad categories which one has to take into account when interpreting the results. Another limitation is that our sample included patients who were seriously ill after all our sample included deceased patients; patients without a life-threatening illness were not included unless their life was ended. On the one hand, this may have led to an underestimation of the number of requests since among those who request EAS are also people who are not seriously ill. On the other hand, it may have led to an overestimation of the number of requests granted among people with a psychiatric disorder, dementia, and/or an accumulation of health problems since physicians are more likely to grant requests of people with (also) a severe and life-limiting somatic condition. 


\section{Conclusions}

A relatively small group of people who died non-suddenly received EAS but even fewer of those with (also) psychiatric disorders, dementia, or an accumulation of health problems. Partly, this can be explained by the belief that the due care criteria cannot be met. Another explanation is that patients with these conditions are less likely to request for it. Given the aging society and the related rising of the number of EAS requests from people suffering from dementia and/or an accumulation of health problems, the question of how policy makers and care providers should respond to these requests is highly relevant.

\section{Abbreviations}

Accumulation of health problems: Accumulation of health problems related to old age; Cl: Confidence interval; EAS: Euthanasia and assisted suicide; OR: Odds ratio

\section{Acknowledgements}

Not applicable

\section{Funding}

This study was funded by the Netherlands Organisation for Health Research and Development (ZonMw, project number 3400.8003)

\section{Availability of data and materials}

The datasets used and/or analyzed during the current study are available from the corresponding author on reasonable request.

\section{Authors' contributions}

$\mathrm{KE}, \mathrm{HP}, \mathrm{AH}, \mathrm{TH}$, and $\mathrm{BO}$ designed the study. The sample was drawn from the central death registry of Statistics Netherlands. KE performed the data management and statistical analysis. $\mathrm{KE}, \mathrm{HP}, \mathrm{AH}, \mathrm{TH}$, and $\mathrm{BO}$ interpreted the data. KE prepared the initial draft of this manuscript. HP, $\mathrm{AH}, \mathrm{TH}$, and $\mathrm{BO}$ critically revised the manuscript for intellectual content and commented on subsequent drafts of the manuscript. $\mathrm{KE}, \mathrm{HP}, \mathrm{AH}, \mathrm{TH}$, and $\mathrm{BO}$ contributed to the final draft of the manuscript and gave the final approval for submission.

\section{Ethics approval and consent to participate}

Under the Dutch Medical Research Involving Human Subjects Act, ethical approval was not required for the posthumous collection of anonymous patient data [22]. Informed consent of the certifying physicians was assumed on return of the survey.

\section{Consent for publication}

Not applicable

\section{Competing interests}

The authors declare that they have no competing interests.

\section{Publisher's Note}

Springer Nature remains neutral with regard to jurisdictional claims in published maps and institutional affiliations.

\section{Author details}

'Department of Public and Occupational Health, Amsterdam Public Health Research Institute, Amsterdam UMC, Vrije Universiteit Amsterdam, P.O. Box 7057, 1007 MB Amsterdam, The Netherlands. ²Department of Public Health, Erasmus University Medical Center, Rotterdam, The Netherlands.

${ }^{3}$ Department of Health Sciences, Amsterdam Public Health Research Institute, Vrije Universiteit Amsterdam, Amsterdam, The Netherlands.
Received: 29 November 2018 Accepted: 31 January 2019

Published online: 19 February 2019

\section{References}

1. Wet toetsing levensbeëindiging op verzoek en hulp bij zelfdoding (Act on termination of life on request and assisted suicide) [statute on the Internet] 2001. Available from: http://wetten.overheid.nl/BWBR0012410/2014-02-15. [Cited: 08-01-2018].

2. Uitspraak Hoge Raad, de zaak-Brongersma (Verdict Supreme Court, the Brongersma case) [statute on the Internet] 24-12-2002. Available from: https:// uitspraken.rechtspraak.nl/inziendocument?id=ECLI:NL:PHR:2002:AE8772.

3. van der Heide A, van Delden JJM, Onwuteaka-Philipsen BD. End-of-life decisions in the Netherlands over 25 years. N Engl J Med. 2017:377(5):492-4

4. Onwuteaka-Philipsen BD, Brinkman-Stoppelenburg A, Penning C, et al. Trends in end-of-life practices before and after the enactment of the euthanasia law in the Netherlands from 1990 to 2010: a repeated crosssectional survey. Lancet. 2012;380(9845):908-15.

5. Onwuteaka-Philipsen BD, Rurup ML, Pasman HR, et al. The last phase of life: who requests and who receives euthanasia or physician-assisted suicide? Med Care. 2010:48(7):596-603.

6. Haverkate I, Onwuteaka-Philipsen BD, van Der Heide A, et al. Refused and granted requests for euthanasia and assisted suicide in the Netherlands: interview study with structured questionnaire. BMJ. 2000;321(7265):865-6.

7. Jansen-van der Weide MC, Onwuteaka-Philipsen BD, van der Wal G. Granted, undecided, withdrawn, and refused requests for euthanasia and physician-assisted suicide. Arch Intern Med. 2005;165(15):1698-704.

8. Meier DE, Emmons CA, Litke $A$, et al. Characteristics of patients requesting and receiving physician-assisted death. Arch Intern Med. 2003;163(13):1537-42.

9. 'Psychiaters te bang bij euthanasie'. Psychiaters krijgen vanuit eigen kring kritiek op hoe ze omgaan met euthanasieverzoeken. NRC [newspaper on the Internet]. 26-10-2017. Available from: https:/www.nrc.nl/nieuws/2017/10/26/ psychiaters-te-bang-bij-euthanasie-13691181-a1578871. [cited 19-07-2018]

10. Appelbaum PS. Physician-assisted death for patients with mental disordersreasons for concern. JAMA Psychiat. 2016;73(4):325-6.

11. de Beaufort ID, van de Vathorst S. Dementia and assisted suicide and euthanasia. J Neurol. 2016;263(7):1463-7.

12. Kouwenhoven PS, Raijmakers NJ, van Delden JJ, et al. Opinions about euthanasia and advanced dementia: a qualitative study among Dutch physicians and members of the general public. BMC Med Ethics. 2015;16:7.

13. Raijmakers NJ, van der Heide A, Kouwenhoven PS, et al. Assistance in dying for older people without a serious medical condition who have a wish to die: a national cross-sectional survey. J Med Ethics. 2015;41(2):145-50.

14. Euthanasia Code 2018. De toetsingspraktijk toegelicht. (Euthanasia Code 2018. The review procedures explained) [report at the Internet] Available from: https://www.euthanasiecommissie.nl/uitspraken/brochures/brochures/ euthanasiecode/2018/euthanasiecode2018. [Cited: 11-09-2018].

15. Regionale Toetsingscommissie Euthanasie. Jaarverslag 2016. (Regional Euthanasia Review Committees. Annual report 2016) [report at the Internet] Available from: https://www.euthanasiecommissie.nl/de-toetsingscommissies/ uitspraken/jaarverslagen/2016/april/12/jaarverslag-2016. [Cited: 10-01-2018].

16. Regionale Toetsingscommissies Euthanasie. Jaarverslag 2013. (Regional Euthanasia Review Committees. Annual report 2013) [report at the Internet] Available from: https://www.euthanasiecommissie.nl/detoetsingscommissies/uitspraken/jaarverslagen/2013/nl-en-du-fr/nl-en-du-fr/ aarverslag-2013. [Cited: 10-01-2018]

17. Regionale Toetsingscommissies Euthanasie. Jaarverslag 2010. (Regional Euthanasia Review Committees. Annual report 2010) [report at the Internet] Available from: https://www.euthanasiecommissie.nl/detoetsingscommissies/uitspraken/jaarverslagen/2010/nl-en-du-fr/nl-en-du-fr/ jaarverslag-2010. [Cited: 10-01-2018]

18. Onwuteaka-Philipsen BD, van der Heide A, Koper D, et al. Euthanasia and other end-of-life decisions in the Netherlands in 1990, 1995, and 2001. Lancet. 2003; 362(9381):395-9.

19. van der Heide A, Onwuteaka-Philipsen BD, Rurup ML, et al. End-of-life practices in the Netherlands under the Euthanasia Act. N Engl J Med. 2007; 356(19):1957-65.

20. Van Der Maas PJ, Van Delden JJ, Pijnenborg L, et al. Euthanasia and other medical decisions concerning the end of life. Lancet. 1991;338(8768):669-74.

21. van der Maas PJ, van der Wal G, Haverkate I, et al. Euthanasia, physicianassisted suicide, and other medical practices involving the end of life in the Netherlands, 1990-1995. N Engl J Med. 1996;335(22):1699-705. 
22. Wet bescherming persoonsgegevens. (Personal Data Protection Act) [statute on the Internet] Available from: http://wetten.overheid.nl/BWBR0011468/ 2018-05-01\#Hoofdstuk1. [Cited: 17-09-2018].

23. Bolt EE, Snijdewind MC, Willems DL, et al. Can physicians conceive of performing euthanasia in case of psychiatric disease, dementia or being tired of living? J Med Ethics. 2015;41(8):592-8.

24. Kouwenhoven PS, Raijmakers NJ, van Delden JJ, et al. Opinions of health care professionals and the public after eight years of euthanasia legislation in the Netherlands: a mixed methods approach. Palliat Med. 2013;27(3):273-80.

25. Snijdewind MC, Willems DL, Deliens $L$, et al. A study of the first year of the end-of-life clinic for physician-assisted dying in the Netherlands. JAMA Intern Med. 2015;175(10):1633-40.

26. Doernberg SN, Peteet JR, Kim SY. Capacity evaluations of psychiatric patients requesting assisted death in the Netherlands. Psychosomatics. 2016:57(6):556-65.

27. van Tol D, Rietjens J, van der Heide A. Judgment of unbearable suffering and willingness to grant a euthanasia request by Dutch general practitioners. Health Policy. 2010;97(2-3):166-72.

28. de Boer ME, Hertogh CM, Droes RM, et al. Suffering from dementia - the patient's perspective: a review of the literature. Int Psychogeriatr. 2007;19(6): 1021-39.

29. van Wijmen MP, Pasman HR, Widdershoven GA, et al. Motivations, aims and communication around advance directives: a mixed-methods study into the perspective of their owners and the influence of a current illness. Patient Educ Couns. 2014;95(3):393-9.

30. Winter L, Parker B. Current health and preferences for life-prolonging treatments: an application of prospect theory to end-of-life decision making. Soc Sci Med. 2007;65(8):1695-707.

31. Onwuteaka-Philipsen B, Legemaate J, van der Heide A, et al. Derde evaluatie Wet toetsing levensbeëindiging op verzoek en hulp bij zelfdoding [Third evaluation of the Termination of Life on Request and Assisted Suicide Act]. Den Haag: ZonMw; 2017

32. Regionale Toetsingscommissie Euthanasie. Jaarverslag 2017. (Regional Euthanasia Review Committees. Annual report 2017) [report at the Internet] Available from: https://www.euthanasiecommissie.nl/de-toetsingscommissies/ uitspraken/jaarverslagen/2017/mei/17/jaarverslag-2017. [Cited: 12-06-2018].

33. Dierickx S, Deliens L, Cohen J, et al. Euthanasia in Belgium: trends in reported cases between 2003 and 2013. CMAJ. 2016;188(16):E407-E14.

34. Twenge, JMC, N.T.; Campbell, W.K. Time period, generational, and age differences in tolerance for controversial beliefs and lifestyles in the United States, 1972-2012. Social Forces 2015;94(1):379-399.

35. Lee CH, Duck IM, Sibley CG. Demographic and psychological correlates of New Zealanders support for euthanasia. N Z Med J. 2017;130(1448):9-17.

36. Collins JW, Zoucha R, Lockhart JS, et al. Cultural aspects of end-of-life care planning for African Americans: an integrative review of literature. J Transcult Nurs. 2018;29(6):578-90.

37. Manalo MF. End-of-life decisions about withholding or withdrawing therapy: medical, ethical, and religio-cultural considerations. Palliat Care. 2013;7:1-5.

38. Ohr S, Jeong S, Saul P. Cultural and religious beliefs and values, and their impact on preferences for end-of-life care among four ethnic groups of community-dwelling older persons. J Clin Nurs. 2017;26(11-12):1681-9.

39. Portanova J, Ailshire J, Perez C, et al. Ethnic differences in advance directive completion and care preferences: what has changed in a decade? J Am Geriatr Soc. 2017;65(6):1352-7.

40. Sachedina A. End-of-life: the Islamic view. Lancet. 2005;366(9487):774-9.

41. Hedberg K, Hopkins D, Kohn M. Five years of legal physician-assisted suicide in Oregon. N Engl J Med. 2003;348(10):961-4.

42. Dierickx S, Deliens L, Cohen J, et al. Involvement of palliative care in euthanasia practice in a context of legalized euthanasia: a population-based mortality follow-back study. Palliat Med. 2018;32(1):114-22.

43. Radbruch L, Leget C, Bahr P, et al. Euthanasia and physician-assisted suicide: a white paper from the European Association for Palliative Care. Palliat Med. 2016;30(2):104-16

Ready to submit your research? Choose BMC and benefit from:

- fast, convenient online submission

- thorough peer review by experienced researchers in your field

- rapid publication on acceptance

- support for research data, including large and complex data types

- gold Open Access which fosters wider collaboration and increased citations

- maximum visibility for your research: over $100 \mathrm{M}$ website views per year

At $\mathrm{BMC}$, research is always in progress.

Learn more biomedcentral.com/submissions 